\title{
SULFONIC ACID-FUNCTIONALIZED LUS-1: AN EFFICIENT CATALYST FOR ONE-POT SYNTHESIS OF 2,4-DIAMINO PYRIMIDINE-5-CARBONITRILE DERIVATIVES
}

\author{
Mahshid Rahimifard, ${ }^{\text {a }}$ Ghodsi Mohammadi Ziarania,*,\# and Alireza Badiei ${ }^{\mathrm{b}}$ \\ aDepartment of Chemistry, Alzahra University, Vanak Square, Tehran, Iran \\ ${ }^{\mathrm{b} S}$ School of Chemistry, College of Science, University of Tehran, Tehran, Iran
}

Recebido em 09/01/2016; aceito em 06/04/2016; publicado na web em 17/06/2016

\begin{abstract}
An efficient acidic functionalization of mesoporous silica LUS-1 (Laval University Silica) and its application as a recyclable heterogeneous catalyst in the synthesis of 2,4-diamino pyrimidine-5-carbonitriles via condensation reaction of aromatic aldehydes, malononitrile and guanidine carbonate in solvent-free condition has been reported. This green method offers a number of advantages such as short reaction time, good yields, simple work-up procedure, recyclable catalyst and environmentally friendly conditions.
\end{abstract}

Keywords: sulfonic acid functionalized LUS-1; 2,4-diamino pyrimidine-5-carbonitrile; guanidine carbonate; nanoporous heterogeneous acid catalyst; solvent-free condition.

\section{INTRODUCTION}

Mesoporous silica materials have recently received significant attention because of their potential applications as catalyst. Grafting organo-acidic groups (e.g., propyl sulfonic acid) to the pore walls of the mesoporous silica materials create various heterogeneous acid catalysts for a wide variety of organic reactions. ${ }^{1-6}$ The LUS-1 is an ordered mesoporous silica with high surface area $\left(800 \mathrm{~cm}^{2} \mathrm{~g}^{-1}\right)$, long range ordered pores (average pore diameter $2-3 \mathrm{~nm}$ ) and hydrothermal stability, ${ }^{7}$ which has the potential to be used as a support material for heterogeneous catalysts. One of the most specific advantages of this material in comparison to other ordered mesoporous silica is different dispersion of hydroxyl groups on the silica surface that leads to higher hydrothermal stability. Furthermore, due to the presence of more $\mathrm{SiOH}$ groups on the silica surface, LUS-1 will be able to react with more surface modifying groups. ${ }^{8}$

Guanidine is a strongly alkaline and water-soluble compound that plays a key role in many biological activities. For example, guanidine affects on the neuromuscular transmission by modifying the release of acetylcholine from the motor nerve. ${ }^{9}$ Also in peptides, residue of arginine has a guanidine structure in the protonated form as guanidinium ion, which functions as an efficient identification moiety of anionic substrates such as carboxylate, nitronate, and phosphate functionalities. ${ }^{10}$ The guanidine groups specify chemical properties of many compounds of medical interest. ${ }^{11}$ For example, sulfadiazine, one of the essential medicines in World Health Organization list, is a sulfonamide antibiotic that contains guanidine substructure. ${ }^{12}$ Using guanidine and its salt as reagent in multicomponent reactions usually leads to the formation of amino pyrimidines, which are a very important class of therapeutic agents and exhibit a wide spectrum of biological activities, such as Tyrosine Kinase inhibitory, ${ }^{13}$ anti-bacterial, ${ }^{14}$ antifolate, ${ }^{15}$ and antitumor activities ${ }^{15}$ There are only few reports for the synthesis of 2,4-diamino pyrimidine-5-carbonitriles via multicomponent reactions of aldehydes, malononitrile and guanidine. ${ }^{16-21}$ However, many of these reported methods suffer from drawbacks such as long reaction times, formation of side products, multistep synthesis, the use of organic solvents, large amount of catalyst and catalysts that cannot be recycled. In continuation of our

*e-mail: gmziarani@hotmail.com;

\#alternative e-mail: gmohammadi@alzahra.ac.ir previous works on the application of heterogeneous solid catalysts in organic synthesis, ${ }^{22-31}$ herein, we would like to report a highly efficient method in the synthesis of 2,4-diamino pyrimidine-5-carbonitriles using LUS-Pr- $\mathrm{SO}_{3} \mathrm{H}$ under solvent-free conditions.

\section{EXPERIMENTAL}

Melting points were measured using the capillary tube method with an electro thermal 9200 apparatus. IR spectra were recorded from $\mathrm{KBr}$ disk using a FT-IR Bruker Tensor 27 instrument. The ${ }^{1} \mathrm{H}$ NMR was run on a Bruker, $250 \mathrm{MHz}$. The ${ }^{13} \mathrm{C}$ NMR was run on a Bruker, 62.9 MHz. Mass spectrometry (MS) analysis was performed on a model 5973 mass-selective detector (Agilent). The $\mathrm{N}_{2}$ adsorption/ desorption measurements were conducted at liquid nitrogen temperature $(77 \mathrm{~K})$ using BELSORP-mini II. X-ray powder diffraction (XRD) patterns were obtained on a Philips X'PERT diffractometer using $\mathrm{Cu}$ $\mathrm{K} \alpha$ radiation at $40 \mathrm{kV}$ and $40 \mathrm{~mA}$. Scanning electron microscopy (SEM) was carried out on a LEO $1445 \mathrm{~V}$ microscope. The TGA was carried out using a PL-Thermal science PL-STA 1500 instrument. Elemental analyses were performed on a Thermo Finnigan Flash EA 1112 series elemental analyzer.

\section{Synthesis of LUS-1}

Colloidal silica Ludox (15.5 g, $0.26 \mathrm{~mol})$ was added to sodium hydroxide $\left(2 \mathrm{~g}, 5 \times 10^{-2} \mathrm{~mol}\right)$ in distilled water $(50 \mathrm{~mL})$ and the mixture was stirred at $70{ }^{\circ} \mathrm{C}$ until a clear solution was obtained (about $24 \mathrm{~h}$ ). A second solution of cetyltrimethylammonium $p$-toluene sulfonate $\left(2.5 \mathrm{~g}, 5.5 \times 10^{-3} \mathrm{~mol}\right)$ in distilled water $(90 \mathrm{~mL})$ was stirred at $40{ }^{\circ} \mathrm{C}$ during $1 \mathrm{~h}$. The first solution was added drop wise to the second one and then the mixture was stirred at $40^{\circ} \mathrm{C}$ for $2 \mathrm{~h}$. The resulting sol-gel was heated at an autoclave at $130^{\circ} \mathrm{C}$ for $20 \mathrm{~h}$. The surfactant was removed by treatment with $\mathrm{HCl} 0.1 \mathrm{~mol} \mathrm{~L}^{-1}$ in ethanol for $2 \mathrm{~h}$. After filtration and washing with distilled water, the synthesized solid was dried under vacuum at $100{ }^{\circ} \mathrm{C} .{ }^{32}$

\section{Functionalization of LUS-1}

The mixture of (3-mercaptopropyl)trimethoxysilane $(12 \mathrm{~mL})$ and LUS-1 (10 g) in dry toluene, was refluxed for $24 \mathrm{~h}$ and then was filtered. The obtained LUS-Pr-SH was washed with acetone and dried. 
Then, LUS-Pr-SH (10 g) was oxidized with $\mathrm{H}_{2} \mathrm{O}_{2}(50 \mathrm{~mL})$ and one drop of $\mathrm{H}_{2} \mathrm{SO}_{4}$ in methanol $(10 \mathrm{~mL})$ for $24 \mathrm{~h}$ at room temperature, then the mixture was filtered and washed with $\mathrm{H}_{2} \mathrm{O}$ and then acetone to obtain pure LUS-Pr- $\mathrm{SO}_{3} \mathrm{H}$ as catalyst.

General procedure for the synthesis of 2,4-diamino pyrimidine5-carbonitrile derivatives

The sulfonic acid functionalized LUS-1 $(0.02 \mathrm{~g})$ was activated in vacuum at $100{ }^{\circ} \mathrm{C}$ and then after cooling to room temperature, aromatic aldehyde $\mathbf{1}(1 \mathrm{mmol})$, malononitrile $\mathbf{2}(1 \mathrm{mmol})$ and guanidine carbonate $3(0.5 \mathrm{mmol})$ were added to it. The mixture was heated $\left(70{ }^{\circ} \mathrm{C}\right)$ in solvent free condition for an appropriate time, as shown in Table 2, and the reaction was monitored by TLC. After the completion of the reaction, the mixture was dissolved in ethyl acetate and filtered to remove heterogeneous catalyst. Ethyl acetate solution was washed several times with water to remove unreacted guanidine carbonate. The ethyl acetate layer was dried with anhydrous magnesium carbonate and concentrated to afford the pure product.

The catalyst was washed with diluted acid solution, water and then acetone, dried under vacuum and reused for several times without loss of significant activity. The spectral data for all compounds are given below.

\section{Spectroscopic data}

2,4-Diamino-6-(4-chlorophenyl)pyrimidine-5-carbonitrile (4a): ${ }^{1} \mathrm{H}-\mathrm{NMR}\left(300 \mathrm{MHz}, \mathrm{DMSO}-d_{6}\right): \delta=7.15-7.76(\mathrm{~m}, 8 \mathrm{H}, 4 \mathrm{CH}$ arom \& $\left.2 \mathrm{NH}_{2}\right) \mathrm{ppm} ;{ }^{21}{ }^{13} \mathrm{C}-\mathrm{NMR}\left(75 \mathrm{MHz}\right.$, DMSO- $\left.d_{6}\right): \delta=76.15$, $117.23,128.52,131.04,135.51,136.72,163.30,165.28,168.65$ ppm; ${ }^{21}$ MS (E. I.) (70 eV): $m / z(\%) 247(18)(\mathrm{M}+2)^{+}, 245(55)\left(\mathrm{M}^{+}\right)$, 203 (25), 75 (25), 43 (100), 28 (58); IR (KBr): $v_{\max }=3506,3428$, $3374,3145,2205,1685,1617,1582,1549,1490,1448,1416,1276$, $1225,1179,1145,1093,1044,1014,873,836,791,711,646,598$, $531,481 \mathrm{~cm}^{-1}$.

2,4-Diamino-6-(phenyl)pyrimidine-5-carbonitrile (4b): ${ }^{1} \mathrm{H}-\mathrm{NMR}\left(300 \mathrm{MHz}, \mathrm{DMSO}-d_{6}\right): \delta=7.12$ (brs, 4H, 2NH${ }_{2}$ ), 7.53 7.76 (m, 5H, 5CH arom) ppm; ${ }^{21}{ }^{13} \mathrm{C}-\mathrm{NMR}$ (75 MHz, DMSO- $d_{6}$ ): $\delta=79.21,116.25,128.03,128.56,130.72,136.18,162.87,164.92$, $169.05 \mathrm{ppm} ;{ }^{21} \mathrm{IR}(\mathrm{KBr}): v_{\max }=3509,3424,3377,3153,2204,1735$, 1674, 1611, 1544, 1490, 1453, 1431, 1276, 1225, 1182, 1143, 1078, $1043,886,803,776,736,700,587,539,502 \mathrm{~cm}^{-1}$.

2,4-Diamino-6-p-tolylpyrimidine-5-carbonitrile (4c): ${ }^{1} \mathrm{H}-\mathrm{NMR}$ $\left(300 \mathrm{MHz}, \mathrm{DMSO}-d_{6}\right): \delta=2.41\left(\mathrm{~s}, 3 \mathrm{H}, \mathrm{CH}_{3}\right), 7.09-7.85(\mathrm{~m}, 8 \mathrm{H}, 4 \mathrm{CH}$ arom \& $\left.2 \mathrm{NH}_{2}\right) \mathrm{ppm} ;{ }^{21}{ }^{13} \mathrm{C}-\mathrm{NMR}\left(75 \mathrm{MHz}, \mathrm{DMSO}-d_{6}\right): \delta=21.93$, $80.73,118.57,128.59,130.62,134.80,140.53,163.45,165.56,169.67$ ppm; ${ }^{21}$ MS (E. I.) $(70 \mathrm{eV}): \mathrm{m} / z(\%) 226(7)(\mathrm{M}+1)^{+}, 225(40)\left(\mathrm{M}^{+}\right), 183$ (20), 155 (20), 116 (18), 89 (22), 65 (25), 43 (100), 28 (46); IR (KBr): $v_{\max }=3428,3377,3349,3165,2203,1715,1634,1541,1444,1409$, $1371,1274,1186,1114,1039,889,831,794,613,568,485 \mathrm{~cm}^{-1}$.

2,4-Diamino-6-(4-methoxyphenyl)pyrimidine-5-carbonitrile (4d): ${ }^{1} \mathrm{H}-\mathrm{NMR}\left(300 \mathrm{MHz}, \mathrm{DMSO}-d_{6}\right): \delta=3.70\left(\mathrm{~s}, 3 \mathrm{H}, \mathrm{OCH}_{3}\right)$, 6.94-7.78 (m, 8H, 4CH arom \& $\left.2 \mathrm{NH}_{2}\right) \mathrm{ppm} ;{ }^{21}{ }^{13} \mathrm{C}-\mathrm{NMR}(75 \mathrm{MHz}$, DMSO- $\left.d_{6}\right): \delta=55.31,75.21,113.51,118.32,129.33,129.85,160.94$, 162.94, 165.21, $168.56 \mathrm{ppm} ;{ }^{21} \mathrm{MS}$ (E. I.) $(70 \mathrm{eV}): \mathrm{m} / z$ (\%) 242 (5) $(\mathrm{M}+1)^{+}, 241(38)\left(\mathrm{M}^{+}\right), 199(12), 66$ (12), 43 (100), 28 (32); IR (KBr): $v_{\max }=3424,3380,3147,2837,2203,1675,1609,1584,1547,1515$, 1493, 1444, 1412, 1303, 1257, 1170, 1116, 1024, 890, 841, 796, 745, $673,574,530,495 \mathrm{~cm}^{-1}$.
2,4-Diamino-6-(3-methoxyphenyl)pyrimidine-5-carbonitrile (4e): ${ }^{1} \mathrm{H}-\mathrm{NMR}\left(250 \mathrm{MHz}, \mathrm{DMSO}-d_{6}\right): \delta=3.77$ (s, $\left.3 \mathrm{H}, \mathrm{OCH}_{3}\right), 7.04-$ $7.41\left(\mathrm{~m}, 6 \mathrm{H}, 4 \mathrm{CH}\right.$ arom \& $\left.1 \mathrm{NH}_{2}\right), 7.50-8.28$ (brs, $\left.2 \mathrm{H}, \mathrm{NH}_{2}\right) \mathrm{ppm}$; ${ }^{13} \mathrm{C}-\mathrm{NMR}\left(62.9 \mathrm{MHz}, \mathrm{DMSO}-d_{6}\right): \delta=55.64,76.45,113.94,116.38$, $118.34,120.86,129.78,138.89,159.33,163.40,165.47,169.63$ ppm; MS (E. I.) (70 eV): m/z (\%) $242(11)(\mathrm{M}+1)^{+}, 241(22)\left(\mathrm{M}^{+}\right)$, 226 (14), 198 (15), 127 (12), 69 (30), 57(42), 43 (100); IR (KBr): $v_{\max }=3424,3360,3141,2918,2648,2199,1678,1630,1560,1509$, 1447, 1426, 1401, 1291, 1243, 1142, 1054, 929, 872, 795, $780 \mathrm{~cm}^{-1}$. Anal. calcd. for $\mathrm{C}_{12} \mathrm{H}_{11} \mathrm{~N}_{5} \mathrm{O}: \mathrm{C}, 59.74 ; \mathrm{H}, 4.60 ; \mathrm{N}, 29.03 \%$. Found: C, 59.69; H, 4.57; N, $29.11 \%$.

2,4-Diamino-6-(4-fluorophenyl)pyrimidine-5-carbonitrile (4f): ${ }^{1} \mathrm{H}$-NMR $\left(300 \mathrm{MHz}, \mathrm{DMSO}-d_{6}\right): \delta=7.05-7.85(\mathrm{~m}, 7 \mathrm{H}, 3 \mathrm{CH}$ arom $\& 2 \mathrm{NH}_{2}$ ) ppm; ${ }^{21}{ }^{13} \mathrm{C}-\mathrm{NMR}\left(75 \mathrm{MHz}\right.$, DMSO- $\left.d_{6}\right): \delta=75.84,115.07$, 115.36, 117.92, 130.57, 133.61, 162.96, 165.02, 168.31 ppm; ${ }^{21}$ IR $(\mathrm{KBr}): v_{\max }=3509,3426,3380,3148,2812.2686,2205,1685,1617$, 1547, 1515, 1450, 1414, 1300, 1278, 1238, 1158, 1102, 1044, 1016, $892,841,807,792,741,708,647,626,568,533,515,478 \mathrm{~cm}^{-1}$.

2,4-Diamino-6-(naphthalen-1-yl)pyrimidine-5-carbonitrile (4g): ${ }^{1} \mathrm{H}-\mathrm{NMR}\left(250 \mathrm{MHz}, \mathrm{DMSO}-d_{6}\right): \delta=7.04$ (brs, $\left.2 \mathrm{H}, 1 \mathrm{NH}_{2}\right)$, 7.18 (brs, $\left.2 \mathrm{H}, 1 \mathrm{NH}_{2}\right), 7.50-7.60(\mathrm{~m}, 4 \mathrm{H}, 4 \mathrm{CH}$ arom), $7.76(\mathrm{~d}, 1 \mathrm{H}$, $J=7.5 \mathrm{~Hz}, 1 \mathrm{CH}$ arom), 7.96-8.02 (m, 2H, 2CH arom) ppm; ${ }^{13} \mathrm{C}-\mathrm{NMR}$ $\left(62.9 \mathrm{MHz}, \mathrm{DMSO}-d_{6}\right): \delta=79.89,117.56,125.550,126.62,127.07$, $128.68,129.76,130.36,133.47,135.69,140.06,163.32,164.86$, 171.26 ppm; MS (E. I.) $(70 \mathrm{eV}): \mathrm{m} / \mathrm{z}(\%) 262(12)(\mathrm{M}+1)^{+}, 261(33)$ $\left(\mathrm{M}^{+}\right), 217$ (35), 191 (22), 126 (14), 43 (100); IR (KBr): $v_{\max }=3568$, 3428, 3327, 3140, 2205, 1639, 1533, 1454, 1419, 1374, 1277, $1235,1087,1034,892,795,776,711,544 \mathrm{~cm}^{-1}$. Anal. calcd. for $\mathrm{C}_{12} \mathrm{H}_{11} \mathrm{~N}_{5} \mathrm{O}: \mathrm{C}, 68.95 ; \mathrm{H}, 4.24 ; \mathrm{N}, 26.80 \%$. Found: C, 68.65; H, 4.21; $\mathrm{N}, 26.92 \%$.

2,4-Diamino-6-(furan-2-yl)pyrimidine-5-carbonitrile (4h): ${ }^{1} \mathrm{H}-\mathrm{NMR}\left(300 \mathrm{MHz}, \mathrm{DMSO}-d_{6}\right): \delta=6.71-7.93(\mathrm{~m}, 7 \mathrm{H}, 3 \mathrm{CH}$ arom $\& 2 \mathrm{NH}_{2}$ ) ppm; ${ }^{21}{ }^{13} \mathrm{C}-\mathrm{NMR}\left(75 \mathrm{MHz}, \mathrm{DMSO}-d_{6}\right): \delta=72.51,112.28$, 114.16, 117.43, 145.57, 150.15, 157.22, 162.96, 165.02 ppm; ${ }^{21}$ IR $(\mathrm{KBr}): v_{\max }=3363,3143,2205,1626,1533,1501,1477,1451,1288$, $1146,1087,1013,942,884,838,788,747,594,528 \mathrm{~cm}^{-1}$.

2,4-Diamino-6-(3,4-dimethoxyphenyl)pyrimidine-5-carbonitrile (4i): ${ }^{1} \mathrm{H} \mathrm{NMR}\left(300 \mathrm{MHz}, \mathrm{CDCl}_{3}\right): \delta=2.2$ (brs, $\left.2 \mathrm{H}, \mathrm{NH}_{2}\right), 3.8$ $\left(\mathrm{s}, 3 \mathrm{H}, \mathrm{OCH}_{3}\right), 3.9$ (s, 3H, $\left.\mathrm{OCH}_{3}\right), 6.75-7.00$ (dd, 2H, 2CH arom), 7.43-7.49 (m, 2H, CH arom), 9.9 (s, $\left.2 \mathrm{H}, \mathrm{NH}_{2}\right)$ ppm; ${ }^{20}{ }^{13} \mathrm{C}-\mathrm{NMR}$ $\left(75 \mathrm{MHz}, \mathrm{CDCl}_{3}\right): \delta=19.30,25.40,56.01,67.00,109.30,110.50$, 121.30, 126.90, 135.00, 144.80, 149.20, 154.60, 170.60 ppm; ${ }^{20}$ IR $(\mathrm{KBr}): v_{\max }=3509,3424,3379,3148,2966,2937,2838,2202,1675$, $1610,1548,1515,1444,1410,1303,1255,1174,1115,1024,889$, $840,794,743,674,652,619,573,532,494 \mathrm{~cm}^{-1}$.

\section{RESULTS AND DISCUSSION}

The synthesis of 2,4-diamino pyrimidine-5-carbonitrile $\mathbf{4}$ were achieved via the three component condensation reaction of aromatic aldehydes 1, malononitrile $\mathbf{2}$ and guanidine carbonate $\mathbf{3}$ using LUS$\mathrm{Pr}-\mathrm{SO}_{3} \mathrm{H}$ as a heterogeneous acid catalyst (Scheme 1). As previously reported in Introduction section, all reported literature used basic catalysts for synthesis of these compound, so we first studied a reaction of 4-chlorobenzaldehyde in the presence of LUS-Pr- $\mathrm{NH}_{2}$ at $70{ }^{\circ} \mathrm{C}$ (Table 1 , entry 1 ). We also studied catalyst free system in the same condition to screen the presence of basic catalyst. As shown in Table 1, entry 2, the presence of basic LUS did not strongly affect the reaction yield and time. Because of this reason, we then studied the 


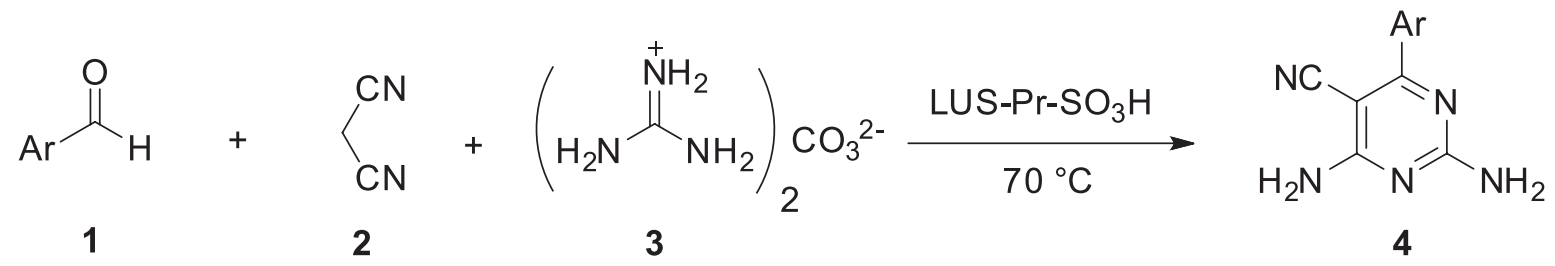

Scheme 1. Synthesis of 2,4-diamino pyrimidine-5-carbonitriles 4 in the presence of LUS-Pr-SO ${ }_{3} \mathrm{H}$

Table 1. The optimization of reaction conditions for the synthesis of $\mathbf{4 a}$ using LUS-Pr- $\mathrm{SO}_{3} \mathrm{H}$

\begin{tabular}{|c|c|c|c|c|c|}
\hline Entry & Catalyst & Solvent & Condition & Time (min) & Yield (\%) \\
\hline 1 & LUS-Pr-NH & Neat & $70{ }^{\circ} \mathrm{C}$ & 15 & 43 \\
\hline 2 & -------- & Neat & $70{ }^{\circ} \mathrm{C}$ & 15 & 40 \\
\hline 3 & LUS-Pr- $\mathrm{SO}_{3} \mathrm{H}$ & Neat & $70{ }^{\circ} \mathrm{C}$ & 3 & 81 \\
\hline 4 & LUS-Pr- $\mathrm{SO}_{3} \mathrm{H}$ & $\mathrm{H}_{2} \mathrm{O}$ & Reflux & 120 & 37 \\
\hline 5 & LUS-Pr- $\mathrm{SO}_{3} \mathrm{H}$ & $\mathrm{EtOH}$ & Reflux & 120 & 49 \\
\hline 6 & LUS-Pr- $\mathrm{SO}_{3} \mathrm{H}$ & Neat & $90{ }^{\circ} \mathrm{C}$ & 3 & 83 \\
\hline 7 & LUS-Pr- $\mathrm{SO}_{3} \mathrm{H}$ & Neat & $50{ }^{\circ} \mathrm{C}$ & 30 & 33 \\
\hline
\end{tabular}

reaction in the presence of LUS-Pr- $\mathrm{SO}_{3} \mathrm{H}$ in the same condition. As shown in Table 1, entry 3 , the acidic catalyst exhibits good activity for synthesis of 2,4-diamino pyrimidine-5-carbonitriles. In order to determine the optimized conditions, we examined the influence of different conditions as shown results in Table 1, entries 4-7. Among the tested conditions the best result was obtained after 3 min at $70{ }^{\circ} \mathrm{C}$ in the presence of LUS-Pr- $\mathrm{SO}_{3} \mathrm{H}$ in solvent-free condition.

After optimizing the reaction conditions, we next developed the best condition for the synthesis of other derivatives using several aromatic aldehydes, as shown results in Table 2. By these conditions, the reactions were carried out easily to produce 2,4-diamino pyrimidine-5-carbonitriles in good yields. This methodology has the ability to tolerate a variety of functional groups such as methyl, methoxy and halides under the reaction conditions. For all substrates, the reaction could be completed in 1-7 min with high yields. After the completion of the reaction, the mixture was dissolved in ethyl acetate and filtered to remove heterogeneous catalyst. Ethyl acetate solution was washed several times with water to remove unreacted guanidine carbonate. The ethyl acetate layer was dried with anhydrous magnesium carbonate and concentrated to afford the pure product. The products were characterized by melting points, ${ }^{1} \mathrm{H} \mathrm{NMR},{ }^{13} \mathrm{C} \mathrm{NMR}$, MS and IR spectroscopic analyses. Melting points are compared with reported values in literature as shown in Table 2.

The acid catalyst can be reactivated by simple washing subsequently with diluted acid solution, water and acetone, and then reused without noticeable loss of reactivity. The reusability of the catalyst was investigated under optimized conditions for the synthesis of the model compound 4a. As shown in Figure 1, the recycling process was completed four times with no significant decrease in the activity of the catalyst. The yields for the four runs were found to be 81,78 , 75 , and $74 \%$, respectively.

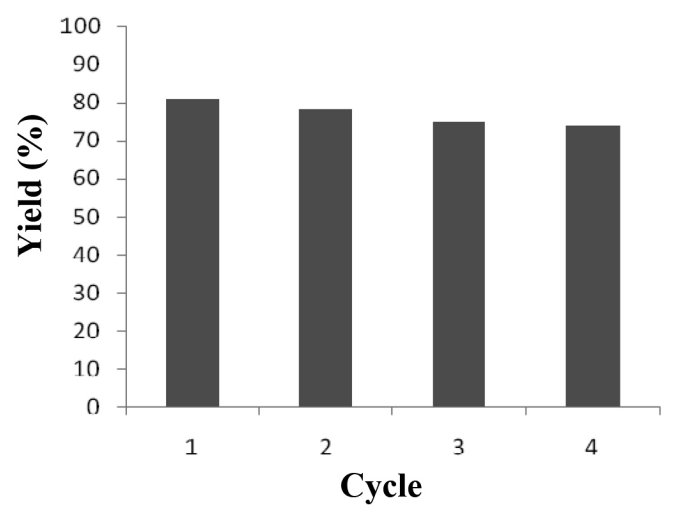

Figure 1. Reusability of LUS-Pr-SO ${ }_{3} \mathrm{H}$ in the synthesis of compound 4 a

In these processes, LUS-Pr- $\mathrm{SO}_{3} \mathrm{H}$ plays an important role in the acceleration of reaction. A suggested mechanism for this transformation is proposed in Scheme 2. LUS- $\mathrm{Pr}-\mathrm{SO}_{3} \mathrm{H}$ acts as a source of $\mathrm{H}^{+}$, which can protonate the carbonyl group of aldehyde and also tautomerize malononitrile. In this reaction, intermediate $\mathbf{5}$ is formed

Table 2. LUS-Pr- $\mathrm{SO}_{3} \mathrm{H}$ catalyzed the synthesis of 2,4-diamino pyrimidine-5-carbonitriles 4 under solvent-free condition

\begin{tabular}{|c|c|c|c|c|c|c|}
\hline Entry & Ar & Product & Time (min) & Yield (\%) & $\mathbf{m p}\left({ }^{\circ} \mathbf{C}\right)$ & mp (Lit) \\
\hline 1 & $4-\mathrm{ClC}_{6} \mathrm{H}_{4}$ & $4 a$ & 3 & 81 & $279-281$ & $281^{19}$ \\
\hline 2 & $\mathrm{C}_{6} \mathrm{H}_{5}$ & $4 b$ & 2 & 85 & $234-236$ & $235-237^{21}$ \\
\hline 3 & 4- $\mathrm{CH}_{3} \mathrm{C}_{6} \mathrm{H}_{4}$ & $4 c$ & 2 & 76 & $255-257$ & $255-257^{16}$ \\
\hline 4 & 4- $\mathrm{CH}_{3} \mathrm{OC}_{6} \mathrm{H}_{4}$ & $4 d$ & 1 & 75 & $238-240$ & $238-240^{21}$ \\
\hline 5 & $3-\mathrm{CH}_{3} \mathrm{OC}_{6} \mathrm{H}_{4}$ & $4 e$ & 2 & 83 & $261-263$ & New \\
\hline 6 & 4- $-\mathrm{FC}_{6} \mathrm{H}_{4}$ & $4 f$ & 4 & 81 & $256-258$ & $243-245^{16}$ \\
\hline 7 & 1-naphthyl & $4 \mathrm{~g}$ & 5 & 69 & $273-275$ & New \\
\hline 8 & 1-furyl & $4 h$ & 7 & 65 & $255-257$ & $265-267^{16}$ \\
\hline 9 & $3,4-\left(\mathrm{CH}_{3} \mathrm{O}\right)_{2} \mathrm{C}_{6} \mathrm{H}_{3}$ & $4 i$ & 2 & 75 & 209-211 & $205^{20}$ \\
\hline
\end{tabular}




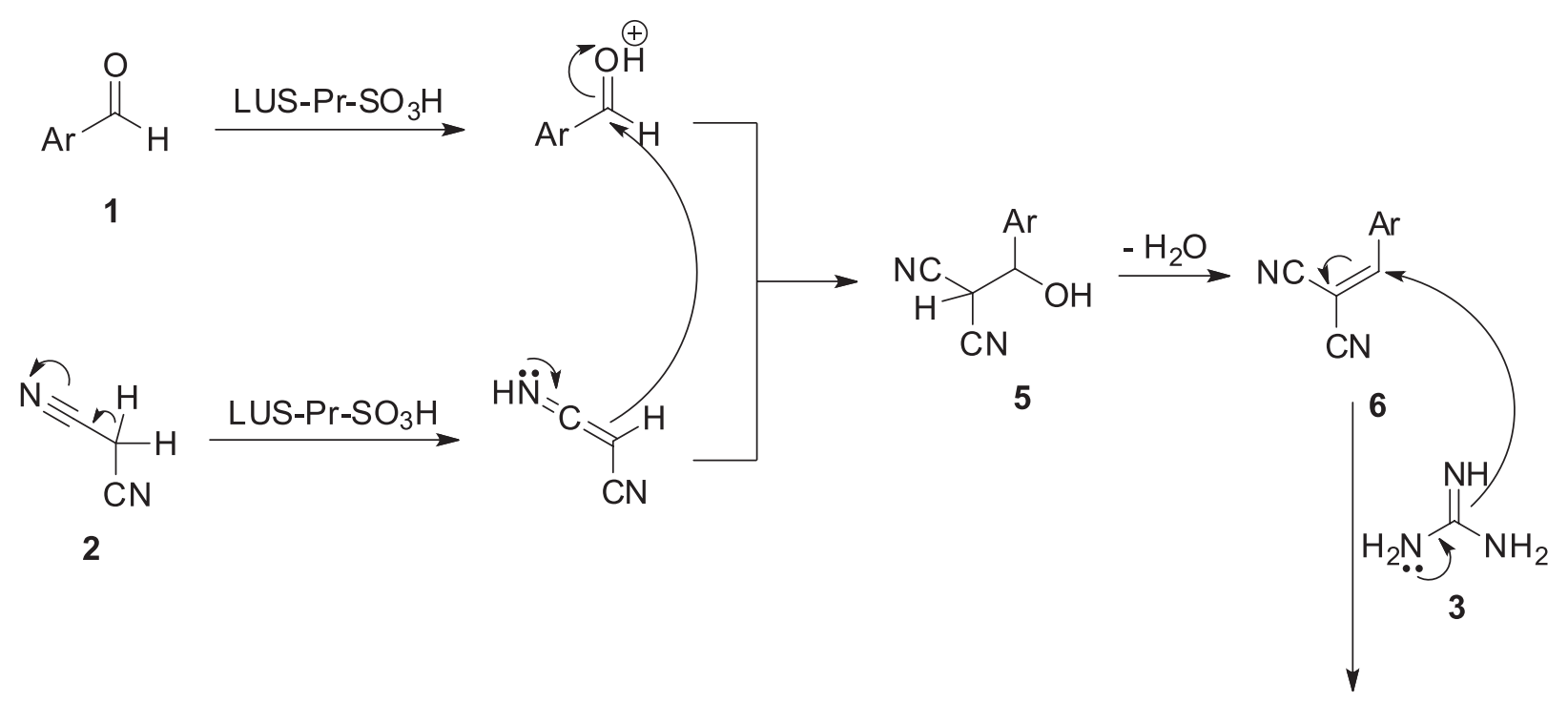<smiles>N#Cc1c(N)nc(N)nc1Br</smiles><smiles>N#CC1C(N)=NC(N)=NC1Br</smiles>

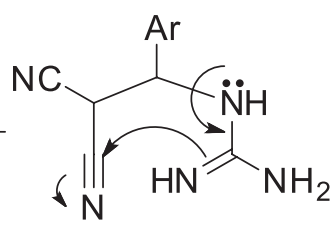

4

Scheme 2. Proposed mechanism for the synthesis of 2,4-diamino pyrimidine-5-carbonitriles 4

through the Knoevenagel reaction between malononitrile and aldehyde, and subsequently olefin $\mathbf{6}$ is produced by dehydration. Subsequent condensation of the guanidine $\mathbf{3}$ and olefin $\mathbf{6}$ followed by cyclization and oxidation affords the corresponding products 4 (a-i). The high yields of reactions are attributed to the effect of nano pore of solid acid catalyst, which could act as nano-reactor.

The synthesis of 2,4-diamino pyrimidine-5-carbonitriles have been studied with several conditions in literature as shown in Table 3. In comparison with other existing methods, the present methodology offers several advantages such as short reaction times, green and reusable catalyst, simple procedure, good yields, simple work-up and solvent-free conditions.

\section{Synthesis and functionalization of LUS-1}

The mesoporous compound LUS-1 was prepared and functionalized according to a previously reported method. ${ }^{31}$ As shown in Figure
2, a solution of cetyltrimethylammonium $p$-toluene sulfonate was added to a mixture of colloidal silica Ludox and sodium hydroxide solution. The LUS-1 was isolated after heating, filtering and removing the surfactant from solid product.

Prepared LUS-1 was functionalized with (3-mercaptopropyl) trimethoxy silane and then, the thiol groups were oxidized to sulfonic acid by hydrogen peroxide (Figure 3 ).

The catalyst was analyzed by different methods such as TGA, $\mathrm{XRD}$, BET and SEM methods which have confirmed that propyl sulfonic acid groups were immobilized into the pores. ${ }^{31}$ Figure 4 illustrates XRD pattern (Figure 4, left) and $\mathrm{N}_{2}$ adsorption-desorption isotherms (Figure 4, right) of LUS-1 and LUS-Pr-SO ${ }_{3} \mathrm{H}$. The XRD pattern of LUS- 1 and LUS-Pr-SO ${ }_{3} \mathrm{H}$ exhibits that grafting of organic group did not affect the structural nature of LUS-1 and volumetric analyses shows "Type IV" $\mathrm{N}_{2}$ adsorption-desorption isotherms with "H1-type" hysteresis which are characteristic of periodic mesoporous materials.

Table 3. Comparison of different conditions in the synthesis of 2,4-diamino pyrimidine-5-carbonitriles 4

\begin{tabular}{|c|c|c|c|c|c|c|}
\hline Entry & Catalyst & Solvent & Condition & Time & Yield $(\%)$ & Year Ref. \\
\hline 1 & High surface area $\mathrm{MgO}$ & $\mathrm{CH}_{3} \mathrm{CN}$ & reflux & $15 \min$ & 88 & $2009^{18}$ \\
\hline 2 & $\mathrm{NaOH}$ & ----- & $70{ }^{\circ} \mathrm{C}$ & Not indicated & 85 & $2010^{16}$ \\
\hline 3 & $\mathrm{NaHCO}_{3}$ & $\mathrm{H}_{2} \mathrm{O} / \mathrm{EtOH}$ & reflux & $5 \mathrm{~h}$ & 81 & $2008^{17}$ \\
\hline 4 & $(\mathrm{Et})_{3} \mathrm{~N}$ & Toluene & MW Irradiation & $25 \min$ & 92 & $2008^{17}$ \\
\hline 5 & ------ & ------ & $200{ }^{\circ} \mathrm{C}$ & $2 \mathrm{~h}$ & 85 & $1990^{19}$ \\
\hline 6 & $\mathrm{~K}_{2} \mathrm{CO}_{3}$ & $\mathrm{H}_{2} \mathrm{O} / \mathrm{TBAB}$ & reflux & $4 \mathrm{~h}$ & 63 & $2008^{20}$ \\
\hline 7 & ------ & {$[\mathrm{bmim}] \mathrm{OH}$} & MW Irradiation $\left(100 \mathrm{~W}, 60^{\circ} \mathrm{C}\right)$ & $2 \min$ & 94 & $2011^{21}$ \\
\hline 8 & LUS-Pr-SO $\mathrm{S}_{3} \mathrm{H}$ & ----- & $70{ }^{\circ} \mathrm{C}$ & $2 \mathrm{~min}$ & 85 & This work \\
\hline
\end{tabular}




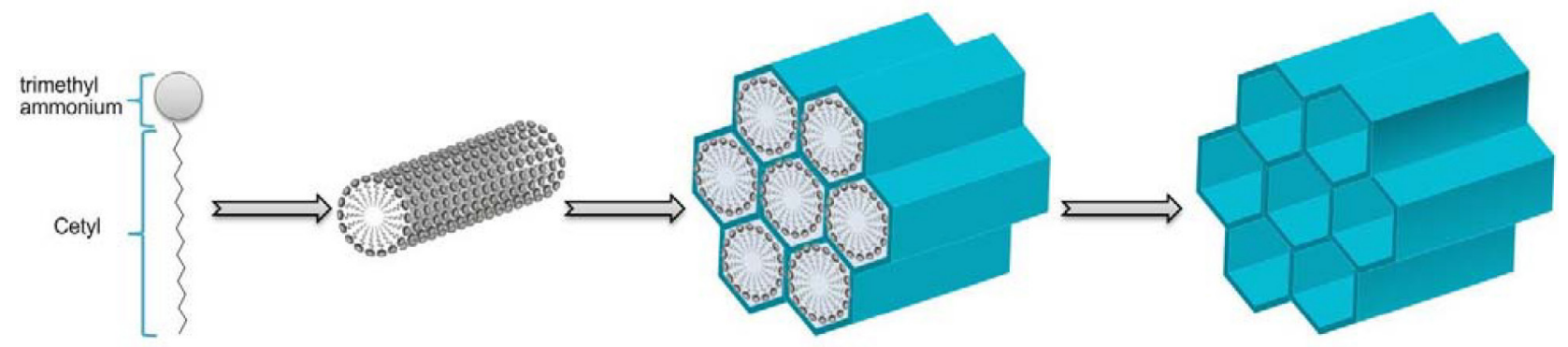

Figure 2. Synthesis of LUS-1
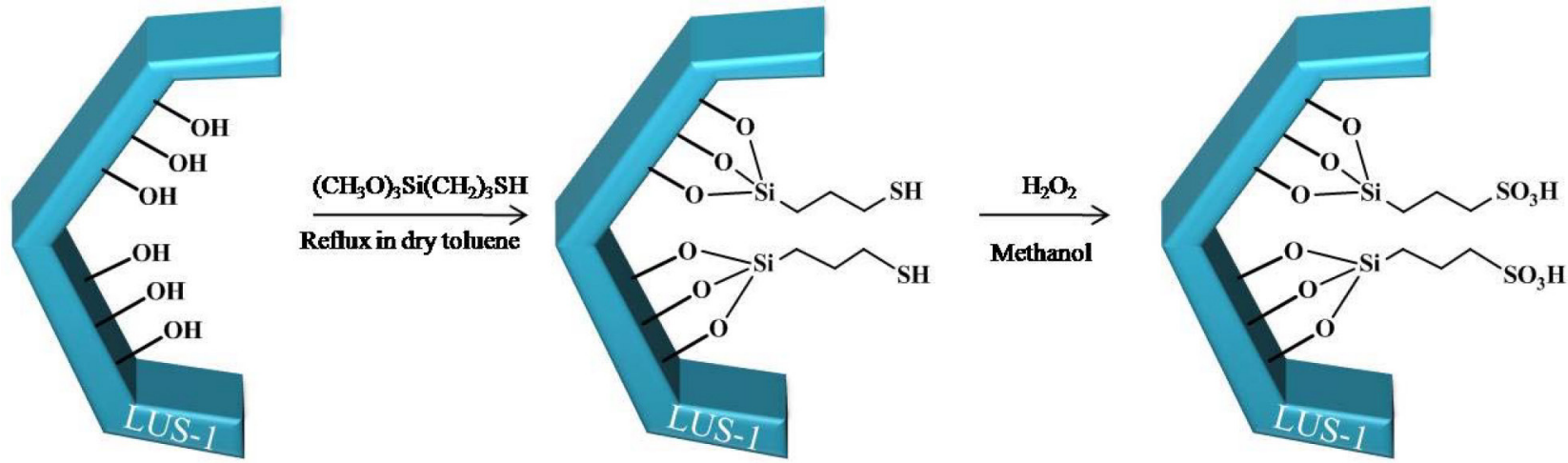

Figure 3. Preparation of LUS-Pr-SO $\mathrm{H}_{3} \mathrm{H}$
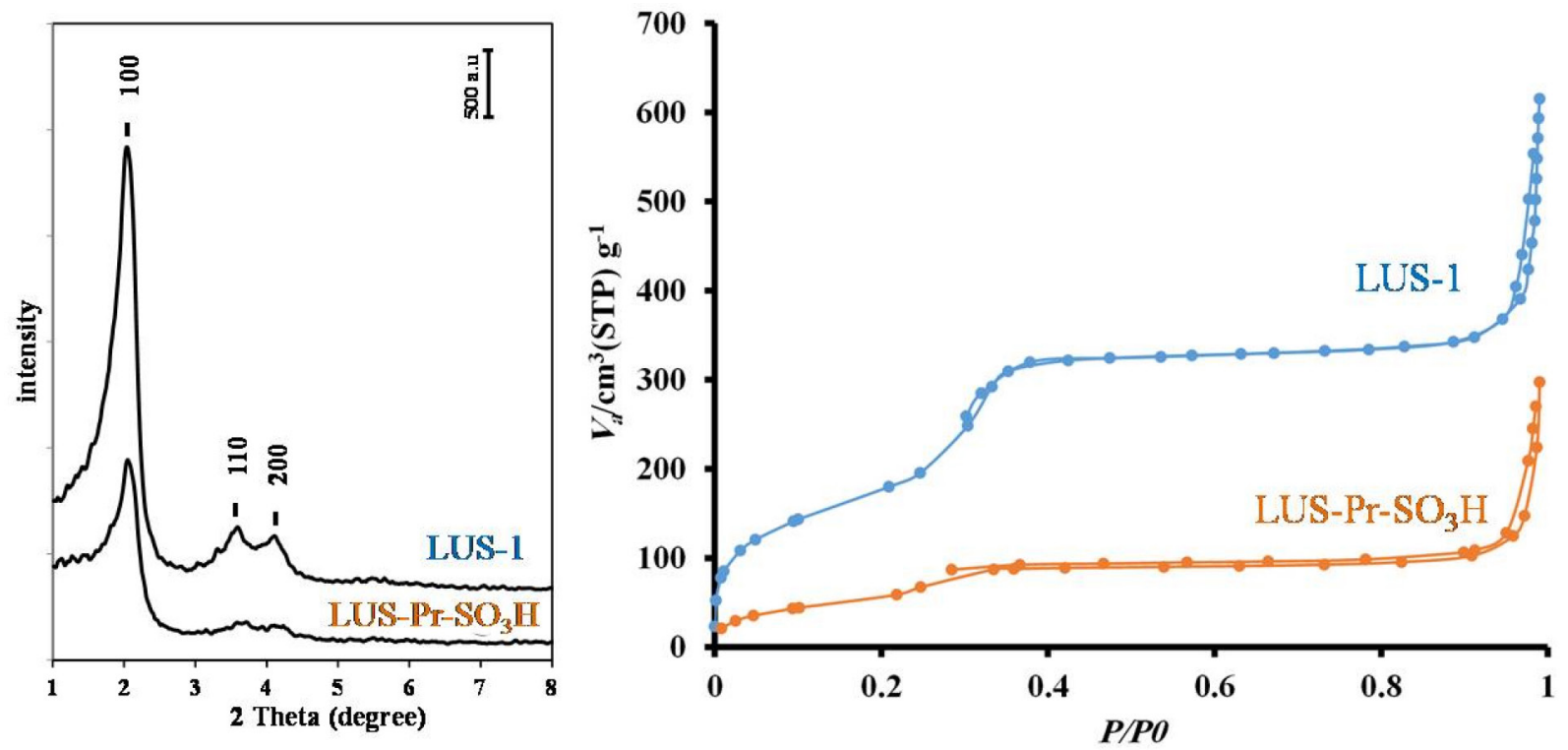

Figure 4. X-ray diffraction pattern (left) and nitrogen adsorption-desorption isotherms (right) for LUS-1 and LUS-Pr-SO ${ }_{3} H$

SEM images of both LUS and LUS-Pr- $\mathrm{SO}_{3} \mathrm{H}$ shows the same morphology, it means the morphology of solid didn't change during the surface modifications (Figure 5).
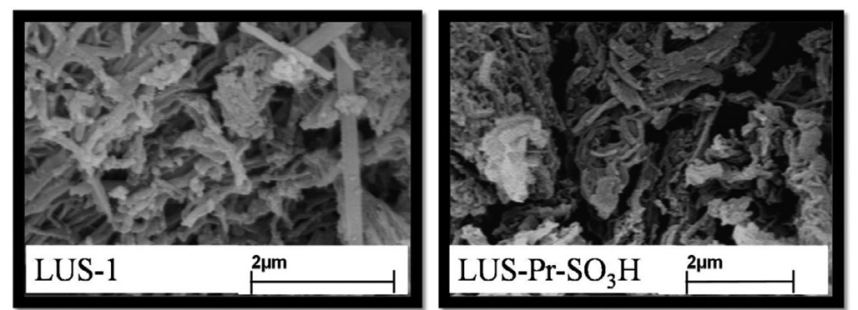

Figure 5. SEM images of LUS-1 and LUS-Pr-SO $\mathrm{S}_{3} \mathrm{H}$

\section{CONCLUSION}

In conclusion, we have established LUS-Pr- $\mathrm{SO}_{3} \mathrm{H}$ as an efficient and recyclable heterogeneous acid catalyst for the synthesis of 2,4-diamino pyrimidine-5-carbonitrile derivatives. The current method does not involve any hazardous organic solvents and the short reaction times and simplicity of the procedure provide significant improvements in comparison to other existing methods.

\section{ACKNOWLEDGMENTS}

We gratefully acknowledge the financial support from the Research Council of Alzahra University and the University of Tehran. 


\section{REFERENCES}

1. Van Rhijn, W. M.; De Vos, D. E.; Sels, B. F.; Bossaert, W. D.; Jacobs, P. A.; Chem. Commun. 1998, 317.

2. Das, B.; Venkateswarlu, K.; Holla, H.; Krishnaiah, M.; J. Mol. Catal. A: Chem. 2006, 253, 107.

3. Onaka, M.; Hashimoto, N.; Kitabata, Y.; Yamasaki, R.; Appl. Catal. A-Gen. 2003, 241, 307.

4. Kureshy, R. I.; Ahmad, I.; Pathak, K.; Khan, N. H.; Abdi; S. H. R.; Jasra, R. V.; Catal. Commun. 2009, 10, 572.

5. Karimi, B.; Zareyee, D.; Org. Lett. 2008, 10, 3989.

6. Mohammadi Ziarani, G.; Lashgari, N.; Badiei; A.; J. Mol. Catal. A: Chem. 2015, 397, 166 .

7. Bonneviot, L.; Morin, M.; Badiei; US patent 01338682003.

8. Reinert, P.; Garcia, B.; Morin, C.; Badiei, A.; Perriat, P.; Tillement, O.; Bonneviot, L.; Cationic tern plating with organic counterion for superstable mesoporous silica; Elsevier, 2003; Vol. 146.

9. Gundersen, C. B.; Jenden, D. J.; Br. J. Pharmacol. 1981, 72, 461.

10. Kamenskaya, M. A.; Elmqvist, D.; Thesleff, S.; Arch. Neurol. 1975, 32, 510 .

11. Wyss, P. C.; Gerber, P.; Hartman, P. G.; Hubschwerlen, C.; Locher, H.; Marty, H.-P.; Stahl, M.; J. Med. Chem. 2003, 46, 2304.

12. Petersen, E.; Schmidt, D. R.; Expert Rev. Anti-infect. Ther. 2003, 1, 175.

13. Boschelli, D. H.; Wu, Z.; Klutchko, S. R.; Showalter, H. D. H.; Hamby, J. M.; Lu, G. H.; Major, T. C.; Dahring, T. K.; Batley, B.; Panek, R. L.; Keiser, J.; Hartl, B. G.; Kraker, A. J.; Klohs, W. D.; Roberts, B. J.; Patmore, S.; Elliott, W. L.; Steinkampf, R.; Bradford, L. A.; Hallak, H.; Doherty, A. M.; J. Med. Chem. 1998, 41, 4365.

14. Deshmukh, M. B.; Salunkhe, S. M.; Patil, D. R.; Anbhule, P. V.; Eur. J. Med. Chem. 2009, 44, 2651.

15. Gangjee, A.; Vidwans, A.; Elzein, E.; McGuire, J. J.; Queener, S. F.; Kisliuk, R. L.; J. Med. Chem. 2001, 44, 1993.
16. Rong, L.; Han, H.; Gao, L.; Dai, Y.; Cao, M.; Tu, S.; Synth. Commun. 2010, 40, 504

17. Sheibani, H.; Saljoogi, A. S.; Bazgir, A.; Arkivoc 2008, 2, 115.

18. Sheibani, H.; Seifi, M.; Bazgir, A.; Synth. Commun. 2009, 39, 1055.

19. Tominaga, Y.; Matsuoka, Y.; Oniyama, Y.; Uchimura, Y.; Komiya, H.; Hirayama, M.; Kohra, S.; Hosomi, A.; J. Heterocycl. Chem. 1990, 27, 647.

20. Deshmukh, M.; Anbhule, P.; Jadhav, S.; Jagtap, S.; Patil, D.; Salunkhe, S.; Sankpal, S.; Indian J. Chem. Sec. B 2008, 47, 792.

21. Raghuvanshi, D. S.; Singh, K. N.; J. Heterocycl. Chem. 2011, 48, 582.

22. Mohammadi Ziarani, G.; Badiei, A.; Khaniania, Y.; Haddadpour, M.; Iran. J. Chem. Chem. Eng. 2010, 29, 1.

23. Mohammadi Ziarani, G.; Badiei, A.; Haddadpour, M.; Int. J. Chem. 2011, 3, 87 .

24. Gholamzadeh, P.; Mohammadi Ziarani, G.; Badiei, A.; Bahrami, Z.; Eur. J. Chem. 2012, 3, 279.

25. Mohammadi Ziarani, G.; Lashgari, N.; Badiei, A.; R. Sci. Iran. 2013, 20,580 .

26. Mohammadi Ziarani, G.; Faramarzi, S.; Asadi, S.; Badiei, A.; Bazl, R.; Amanlou, M.; DARU J. Pharm. Sci. 2013, 21, 3.

27. Mohammadi Ziarani, G.; Mousavi, S.; Rahimifard, M.; Badiei, A.; $J$. Mex. Chem. Soc. 2014, 58, 168.

28. Mohammadi Ziarani, G.; Hosseini Nasab, N.; Rahimifard, M.; Abolhasani Soorki, A.; J. Saudi Chem. Soc. 2015, 19, 676.

29. Mohammadi Ziarani, G.; Rahimifard, M.; Nouri, F.; Badiei, A.; J. Serb. Chem. Soc. 2015, 80, 1265 .

30. Mohammadi Ziarani, G.; Nouri, F.; Rahimifard, M.; Badiei, A.; Abolhassani Soorki, A.; Rev. Roum. Chim. 2015, 60, 331.

31. Rahimifard, M.; Mohammadi Ziarani, G.; Badiei, A.; Asadi, S.; Abolhasani Soorki, A.; Res. Chem. Intermed. 2016, 42, 3847

32. Hashemi, P.; Badiei, A.; Shamizadeh, M.; Mohammadi Ziarani, G.; Ghiasvand, A. R.; J. Chin. Chem. Soc. 2012, 59, 727. 